\title{
伝統的な水辺のアース・デザインの 型とデザイン原則に凪する研究。
}

A study on design types and design principles of historical earth design in waterfront

上島顕司 $\cdots$ 篠原 修 $\cdots$

By Kenji Ueshima, Osamu Shinohara

\begin{abstract}
The purpose of this article is to find design types and principles as to earth design in historical waterfront.

By analyzing characteristics of these design types, earth design in waterfront controling wateredge's form could be stood as design of sophistcating or emphasizing spatial potential that natural wateredges have.

And all design types we have found can be ordered by three axes of basical spatial characteristics in view of design.
\end{abstract}

\section{1 研究の目的}

近年、水辺の整備が盛んであるが、その実態は、 空間の骨格やイメージを決める水際線や地形には手 を触れず、ベンチや植栽やカラー舗装を対象とする 表層的な段階に留まっており、水辺という場所が本 来、持っている豊かな内容をデザインに生かしてい るとは思えない場合が多い。その理由は、水辺らし さとは何かが分かっていない、少なくとも、設計に 使用できる用語として整理されていないことに一因 があると思われる。

単なる水陸のエッジである水際線そのものは何の

\footnotetext{
*キーワース 水辺 アースデザイン 型

**正会員 運輸省港湾技術研究所

（テ239 横須賀市長瀨3-1-1）

****正会員 工博 東京大学助教授 工学部土木工学科

（テ113 文京区本郷7-3-1）
}

意味も持たないが、人間との付き合い（利用）の歴 史の中で水際線は人間にとってある意味を持って来 るようになると考えられる。そのように長い時間を かけて得られた利用と一体になった水際線のデザイ ンが、我々の知りたい水辺らしい水辺のデザイン、 即ち、水辺のアース・デザインである。 水辺のアース・デザインについては、既に筆者ら のグループが自然らしい水辺の形について分類した もの 1)を除けば、事(例) 、提案314)5)、設計思想6) のレベルのものが主であり、実際の計画、設計にお いて根扰となる知見を与えるような具体的な空間の 形の収集、整理は今までに行われていない。

そこで、本論文は、利用する人々にとって、潜在 的な意味が充分に表出していたと考えられる伝統的 な水辺から、水辺のアース・デザインを発掘、整理 することを目的とする。

しかし、今回の研究ではデザインの型の発掘、分 析に主眼を置いたため、ある水辺が必ずどれかのデ 
ザインの型に当てはまるようには体系づけられてい ない。

また、筆者らは他にも街並み（建築物の集合状態） 道、眺望についても伝統的な水辺のデザインの型の 抽出とデザイン原則の分析を行ったが、これらにつ いては紙面の都合から別の機会に講ることにする。

\section{2 研究の対象}

本論文で対象とした伝統的な水辺は名所としての 水辺である。名所はレクリエーションだけではなく 宗教、生活、産業の場でもあったが、いずれも人々 が参集し関心をよせた場であり、そのデザインにつ いて気が配られてきたと考えられるからである。

更に、対象とした時代、地域、スケールは以下の 通りである。

(1) 時代としては江戸期〜明治初期を対象とした。 これは、この時代の主役となった交通手段力船運 であること、また水辺には多くの名所があり、その デザインが成熟していたと考えられることによる。

(2) 地域としては、都市域の海岸、港、河川の河口 部周辺、堀割運河を対象とした。

農村域、自然域等では水辺のデザインや利用の形 態は異なると予想されるが、現在の関心、需要の高 いのは都市域の水辺であること、文化の集積が大き くデザインの成熟度が高いと考えられること等から 都市域の水辺を対象としたものである。

また、人々の水辺に託していた意味を知るのが目 的であるから、内陸の池や湖であっても興味深い事 例の場合には、適宜、取入れて参考にした。

(3) 対象のスケールとしては、半島などの数 $\mathrm{km}$ m スケールではなく、人間が改変、造成可能であった 数mから数百mのスケールの事例を扱った。

3 研究の方法

3-1 型の抽出

(1) 形の抽出

過去の諸資料の中から、ある水際線の「形」をデ ザインの「型」として採用するために満たすべき条 件を次のように定めた。

以下に述べる「形と利用に関する要件」の1)の条 件を蔳たし、かつ「評価に関する要件」の1) 4)の いずれかの条件を満たすこと。または、「形と利用
に関する要件」の2)を満たし、かつ「評洒に関する 要件」と「デザインに関する要件」を満たすこと。

但し、後者の場合には事例数が例え少数であって も、

・ 内容の比較から他のデザインを位置づけること になること。

・今回の研究では発見されなかったが、より広く 調查すれば、事例が増すことも考えられること。 ・今回の研究はデザインの発掘に主眼があり、こ のような観点からの研究が少ないことからも、

発表しておく意義があること。 等の理由から型として採用することにした。

・形と利用に関する要件

1）同一の「形」で同一の「利用」がなされ ていること。

2）他と著しく異なる独特の形を持ち、興味 深い利用をしているもの。

・評価に関する要件

1） 宗教空間、遊興空間等のレクリエーショ ンの場となっており、人がよく集まる空間 であったこと。

2）名所図絵に載っている、或は幾つかの絵 図等に登場するなど著名な空間であったこ と。

3）その場所で詩歌等が作られている、絵図 の解説等て評価されている等、当時から評 価就かったこと。

4）現在も、存在し（人が集まる、著名であ る等) 評洒动高いこと。

・デザインに関する要件

1）現在の水辺のデザイン用語の筫困さから みて示唆深いと思われるもの。

「形と利用に関する要件」1)、2)でいう形とは、 凹凸等の定性的な空間の形をいい、利用については、 宗教装置（寺、神社、阔、鳥居等）、植裁、アクセ ス装置 (雁木、栈橋、スロープ等)、住居等建筑物、 船、人等が描かれているかどうかを目安にした。

\section{（2）空間の把握}

次に、絵図だけでなく、同一場所の地図、絵画等 を集めることによって、空間の形、利用を具体的に 把握することに努めた。

(3) 利用の特定 
絵図等の解説、その他、市史、港史、地名辞典等 の文献等によってその空間がどの様に利用されてい るかを確認した。原則として、文献上の確珰がとれ ないものについては「型」として採用しなかった。

(4) 型の命名

（1）（3）によって、空間の形と利用、特性 を特定できたものについては型の名前を命名した。 3-2 型の分析

\section{（1）型の分類}

抽出した型を水際線の平面若しくは断面形状を操

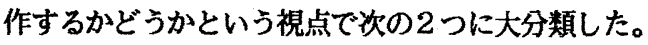
a ）原地形利用デザイン

水際線の形状は変更せず、装置、施設等を付加す ることによって空間に意味づけを行い、ある特定の 利用を促すデザイン手法をいう。

b ） 水辺のアースデザイン

水際線の平面若しくは断面形状を操作し、時には 何等かの装置等を加えるデザイン手法をいう。

水際線を操作したか否かの判断は以下によった。

1）人工的な護岸等の見られる場合。

2）人工の手を加えたと考えない限り不自然な形 状、配置、大きさである場合。

3）文献等で造成したことが確認できた場合。

（2）空間特性の抽出

原地形利用デザインの型は、原地形に対応して人 間にとって特有の利用パターンが存在することを示 している。この原地形の利用を方向づける空間特性 を明かにした。

(3) デザイン原則の抽出

原地形や空間特性との関係からアースデザインに 関するデザイン原則を得た。

\begin{tabular}{|c|c|c|}
\hline 分 類 & 項 目 & 例 \\
\hline 秢画資料 & 名所四絵、浮世淞、四誌、写真 & 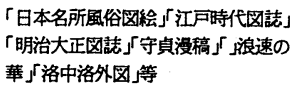 \\
\hline 地図資料 & $\begin{array}{l}\text { 古地図、切絵図、延桧図、旧版 } \\
\text { 地形図 }\end{array}$ & 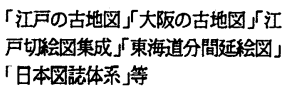 \\
\hline 文献資料 & $\begin{array}{l}\text { 市史、港史、地誌、桧四等の解 } \\
\text { 説 }\end{array}$ & $\begin{array}{l}\text { 「大阪市史」大阪港史」「江東区史」 } \\
\text { 「東京市史稿(港海祦)」等 }\end{array}$ \\
\hline
\end{tabular}

$3-3$ 資料

資料としては、表一 1 を用いた。この種の従来の 研究と異なり、罒桧等だけでなく、地図、文献資料 も併せて用いるようにした。

\section{4 水辺の原地形の型と空間特性}

水辺において「同じ形」で「同じ利用」がされて おり、人工的な改変加加えられていないと考えられ る地形 (原地形) を抽出、整理することで、表-2 の7型を得た。河口に関する語棠劸いのは近世に おいて都市は河口部に発展することが多く、必然的 にその周辺に語棠勃偏ることになった為であると考 えられる。ここで得られた原地形は、あくまで、地 形と人々の利用か顕著で「型」として抽出できたも のだけに限っているので、水辺の原地形を網羅する ように「型」が体系化されている訳ではない。

以下、紙面の都合から原地形の主要な 4 型につい て解説し、空間特性を明らかにする。「浜」「丘」 型とその空間特性である「平坦性」「眺望性」「自 然性」は水辺とまちの関係づけ（街並、道、眺望） のデザインにおける重要な空間特性であるが本論文 では解説しない。

\section{a）「崎」型}

「水面に対し凸状に突出した地形」をいう。 江戸郊外、鈴力゙森（図一1）のように、水面に突 出した地形には樹木や洅、人が描かれた。従って、 このような形状の空間は、人々か好む視点となりゃ すく、人をそこに呼び込みやすいという性格を持っ ていると思われる。このような特性（空間の性格） を持つ架間を「突出型」と呼び、その空間特性を「 誘引性」と呼ぶことにする。

\section{b)「浦」型}

「水面に対し凹状の平面形状を持つ地形」をいう。 水面に対し凹状の空間には、図一2のように水域 の奥に家や集落、舟付き場が存在したり、時には人 々の屋外のレクリエーションの場となったりした。 従って、この形状の空間は人間にとって居住性や 安息性に富み、よりどころや活動の扰点となりやす い特性を持っていると思われる。このような特性を 持つ空間を「浦型」、その空間特性を「扰点性」と 呼ぶことにする。 
表-2 原地形の型

\begin{tabular}{|c|c|c|c|c|c|c|}
\hline \multirow{2}{*}{\multicolumn{2}{|c|}{ 型 }} & \multirow{2}{*}{ 定 羲 } & \multicolumn{2}{|c|}{ 特 性 } & \multirow{2}{*}{ 利用・流設 } & \multirow{2}{*}{ 事 例 } \\
\hline & & & 出現地域 & 空間特性 & & \\
\hline $\begin{array}{c}\text { 「浜」型 } \\
\text { hama }\end{array}$ & & $\begin{array}{l}\text { 海辺の平坦で開け } \\
\text { た地形 }\end{array}$ & 海 & $\begin{array}{l}\text { 平坦 } \\
\text { 眺幄性 } \\
\text { 自然性 }\end{array}$ & 松林 & \begin{tabular}{|l} 
打出の浜 \\
吹上の浜等
\end{tabular} \\
\hline $\begin{array}{l}\text { 「乒」型 } \\
\text { oka }\end{array}$ & & $\begin{array}{l}\text { 利用か冰面と関係 } \\
\text { のある水辺近くの } \\
\text { 丘陵 }\end{array}$ & 海·河川 & 眺望性 & $\begin{array}{l}\text { 日和山 } \\
\text { 名所 } \\
\text { 寺社·大名 } \\
\text { 屋數·別荘 }\end{array}$ & 御殿山等 \\
\hline $\begin{array}{c}\text { 「浦」型 } \\
\text { ura }\end{array}$ & & $\begin{array}{l}\text { 水面に対し凹状の } \\
\text { 面形状を持つ地 } \\
\text { 形 }\end{array}$ & \begin{tabular}{|l|} 
海 \\
河川
\end{tabular} & 拠点性 & $\begin{array}{l}\text { 家·集落 } \\
\text { 船揚場 } \\
\text { 船溜り }\end{array}$ & 鞆の浦等 \\
\hline $\begin{array}{c}\text { 「崎」型 } \\
\text { saki }\end{array}$ & & $\begin{array}{l}\text { 水面に対し凸状の } \\
\text { 平面形状を持つ地 } \\
\text { 形 }\end{array}$ & \begin{tabular}{|l|} 
海 \\
河川
\end{tabular} & 誘引性 & $\begin{array}{l}\text { 樹木·菏 } \\
\text { 波止·埠頭 } \\
\text { 橋台·川床 }\end{array}$ & $\begin{array}{l}\text { 鈴が森、唐崎 } \\
\text { 等 }\end{array}$ \\
\hline $\begin{array}{c}\text { 「中州」型 } \\
\text { nakasu }\end{array}$ & & $\begin{array}{l}\text { 河川に見られる砂 } \\
\text { 州状の島 }\end{array}$ & 河川 & $\begin{array}{l}\text { 隄離性 } \\
\text { 扔点性 }\end{array}$ & $\begin{array}{l}\text { 料理屋街 } \\
\text { 遊邡・川床 } \\
\text { 橋、渡し場 }\end{array}$ & $\begin{array}{l}\text { 江戸中洲、加 } \\
\text { 茂川、大坂中 } \\
\text { 之島等 }\end{array}$ \\
\hline 「砂州」型 & & $\begin{array}{l}\text { 河口部の一方の端 } \\
\text { から発達する砂地 }\end{array}$ & 河口部 & $\begin{array}{l}\text { 誘引性 } \\
\text { 誘渉性 }\end{array}$ & $\begin{array}{l}\text { 神社(先端) } \\
\text { 殿篗茶屋 } \\
\text { 樹木 }\end{array}$ & $\begin{array}{l}\text { 梁川州崎、品 } \\
\text { 川州猗、羽田 } \\
\text { 州猗等 }\end{array}$ \\
\hline $\begin{array}{l}\text { 「島」型 } \\
\text { sima }\end{array}$ & & $\begin{array}{l}\text { 利用が陸域と関係 } \\
\text { する陸域近くの島 }\end{array}$ & 海 & 隔離性性 & 神社、䄑 & 岩屋 \\
\hline
\end{tabular}

c）「中州」型

「河川に見られる砂州状の島」を いう。

大坂中之島は中州全体が米市であ つた。また、安永元年〜天明 8 年 ( 1772-1786）まで江戸隅田川に築かれ ていた中洲は料亭街、遊邡であった 73、8)。このように都市内である程度 の規模を持つ河川の中の島は、町屋 が立ち並ぶ小都市となることがあっ た。

また、瀬田川や加茂川（図-3） 等の小規模な場合は、渡しや連続橋 の橋台などの扰点となったり、川床 等がでる納涼の場となった。

即ち、都市域においてある程度の まとまりを持ったこのような形状の 空間は、水面によって周囲と隔離さ れていることから、周囲と異なった 特定の土地利用（特にレクリエーシ ヨン) の場としてまとまり易かった ことが分かる。
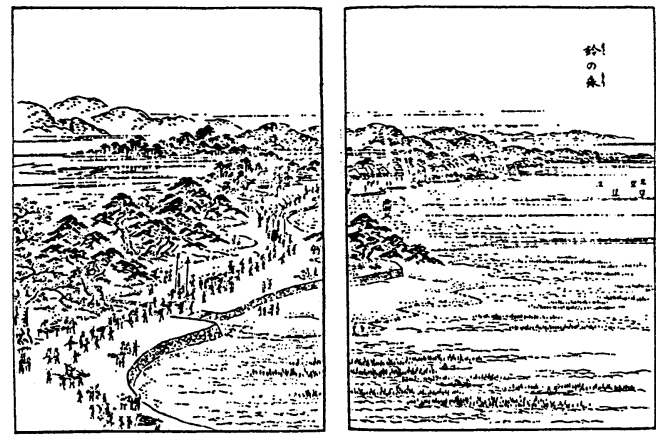

図-1 江戸鉿が森 (猗型)
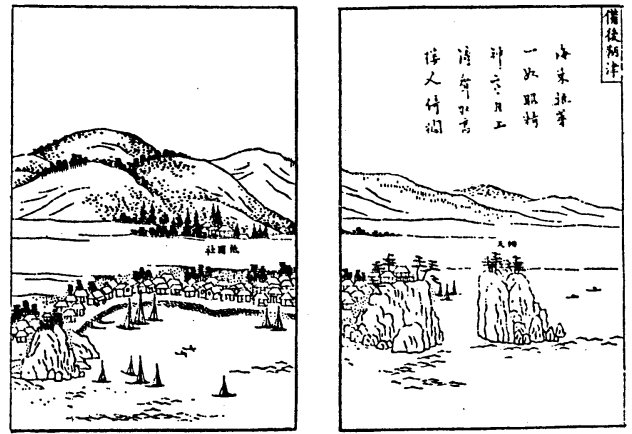

図-2 鞆の浦 (浦型)

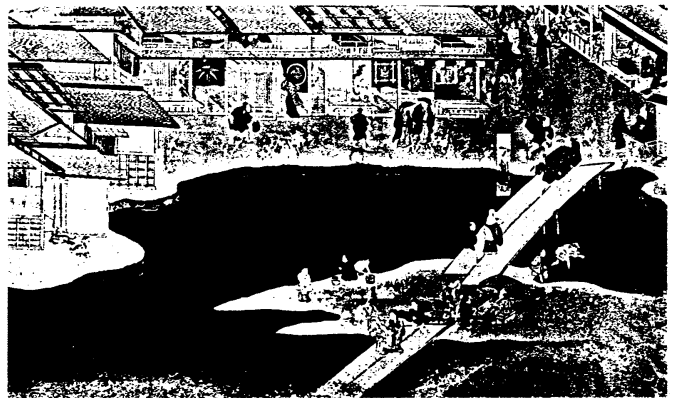

図-3 加茂川 (中州型)

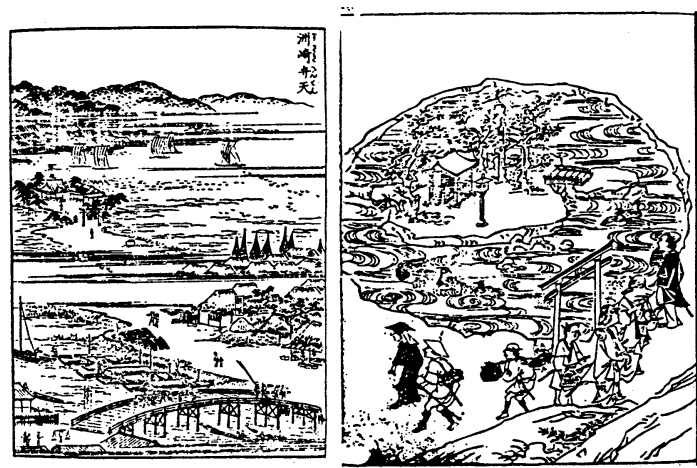

図-4 品川州崎 (砂州型)図一 5 不忍の池 (独立島型) 
表 -3 水辺のアース・デザインの型

\begin{tabular}{|c|c|c|c|c|c|c|}
\hline \multicolumn{2}{|c|}{ 型の名称 } & 定義 & $\begin{array}{l}\text { 関連する } \\
\text { 原地形 }\end{array}$ & 空間特性 & 施設·和用 & 事例 \\
\hline 突出型 & 8 & \begin{tabular}{|l} 
平面形状に於て水 \\
面側に突出する形 \\
態
\end{tabular} & $\begin{array}{l}\text { 「崎」 } \\
\text { 「砂州」 }\end{array}$ & 誘引性 & $\begin{array}{l}\text { 埠頭·找相 } \\
\text { 水制工工 } \\
\text { 伽藍石(庭) }\end{array}$ & 州崎明神、東屋 \\
\hline 独立島型 & 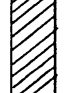 & $\begin{array}{l}\text { 陸地と暒がクのな } \\
\text { W人工島 }\end{array}$ & 「島」 & $\begin{array}{l}\text { 隔離性 } \\
\text { 誘引性 } \\
\text { 拋点性 }\end{array}$ & $\begin{array}{l}\text { 神社(弁天) } \\
\text { 椡木 }\end{array}$ & $\begin{array}{l}\text { 初期不忍池、大 } \\
\text { 坂波除島 }\end{array}$ \\
\hline 隅入り型 & 政 & $\begin{array}{l}\text { 平面形状に於て隅 } \\
\text { 入りの济を作る }\end{array}$ & 「浦」 & 拠点性 & $\begin{array}{l}\text { 栈槽、河岸、 } \\
\text { 船潘り、鳥居 }\end{array}$ & $\begin{array}{l}\text { 鹿鳥神宮一の鳥 } \\
\text { 居等 }\end{array}$ \\
\hline 内水面型 & 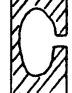 & $\begin{array}{l}\text { 水面を陸地側に取 } \\
\text { 込むもの }\end{array}$ & 「浦」 & 拠点性 & $\begin{array}{l}\text { 汐入庭圆 } \\
\text { 社家町 } \\
\text { 料亭 }\end{array}$ & 大名庭園 \\
\hline 分水型 & 1 & $\begin{array}{l}\text { 水面を主水面と副 } \\
\text { に分割する空間 }\end{array}$ & 「中州」 & 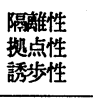 & $\begin{array}{l}\text { 料亭· 茶屋 } \\
\text { 並木 }\end{array}$ & $\begin{array}{l}\text { 不忍の池新土手 } \\
\text { 大坂十三間堀川 } \\
\text { 等. }\end{array}$ \\
\hline 堭堤型 & & 水面を分割する道 & & 誘歩性 & $\begin{array}{l}\text { 並木、橋、橋 } \\
\text { 台 }\end{array}$ & $\begin{array}{l}\text { 金沢瀬戸神社- } \\
\text { 州畸明神間 }\end{array}$ \\
\hline 出島型 & & $\begin{array}{l}\text { 水面に囲まれた陸 } \\
\text { 域空間 }\end{array}$ & 「崎」 & $\begin{array}{l}\text { 誘引性 } \\
\text { 拠点性 }\end{array}$ & $\begin{array}{l}\text { 遊斿、外国人 } \\
\text { 居留地 }\end{array}$ & $\begin{array}{l}\text { 横浜関内、出島 } \\
\text { 等 }\end{array}$ \\
\hline 弁天島型 & & $\begin{array}{l}\text { 陸橋及び橋によっ } \\
\text { て陸地と鑔がった } \\
\text { 人工島、自然の島 }\end{array}$ & 「島」 & $\begin{array}{l}\text { 隔離性 } \\
\text { 誘引惺 } \\
\text { 趑点性 }\end{array}$ & $\begin{array}{l}\text { 神社、樹木 } \\
\text { 茶屋、橋、陸 } \\
\text { 橋 }\end{array}$ & $\begin{array}{l}\text { 瀬戸弁天、不忍 } \\
\text { 池等 }\end{array}$ \\
\hline 天保山型 & 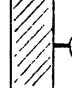 & $\begin{array}{l}\text { 山や運河、入り江 } \\
\text { 等が造られ多機能 } \\
\text { 化している人工島 }\end{array}$ & 「島」 & $\begin{array}{l}\text { 隔離性 } \\
\text { 誘引性 } \\
\text { 拠点性 }\end{array}$ & $\begin{array}{l}\text { 樹木、茶屋 } \\
\text { 船溜り、橋 } \\
\text { 石燈能 }\end{array}$ & 天保山 \\
\hline
\end{tabular}

このような形状と特性を持つ空 間を「中州型」と呼び、その空間 特性を「隔離性」「扰点性」と呼 ぶことにする。

d)「砂州」型

「河口部の一方の端から発達す る砂地」をいう。

江戸の深川洲猗、品川洲㥓（図 - 4) 羽田洲崎、神奈川の金沢洲 崎などには河口からのびた砂州の 先端部にこんもりとした森を伴っ た弁天か祭られた。これは、航行 目標であったと共に、多くの名所 図絵に描かれた名所であり、レク リエーションの場でもあった。

このように、先端に人を誘う特 性を持っている形状の空間を「砂 州型」と呼ぶ。この型は「猗型」 の特化した空間であるとも考えら れる。
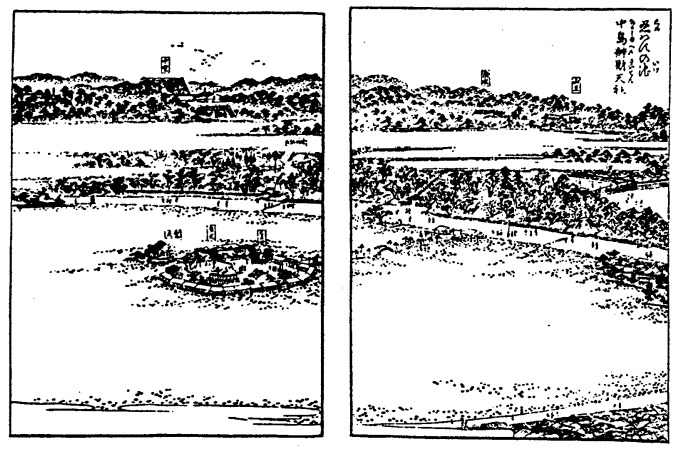

図-6 金沢瀬戸弁天（弁天島型）
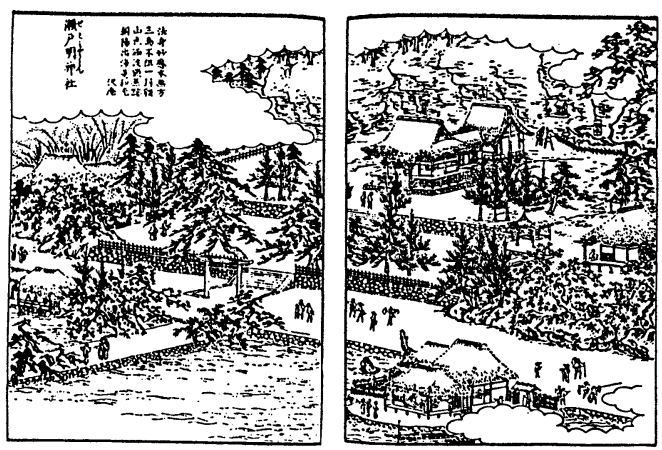

図-7 金沢州渏明神（突出型）
5 水辺のアース・デザインの型

水際線の形状を操作する水辺のアース・デザイン としては表-3の9型を抽出した。以下、主要な 5 型について解説する。

a) 独立島型

「陸地と僖がりのない人工島」をいう。 江戸不忍池の弁天島は寛永年間(1624-1644)、琵琶 湖の竹生島の見立てとして作られた人工島であった。 (図－5）そこには弁天か祭られ、人々は船でお参 りをするようになっていた91、1も。 水面によって隔離されることで宗教的な有難みが 増すと考えられていたと思われる。このような水面 による隔離性をアース・デザインとして取り入れた ものとしては、他にも浄土式庭園の例がある。 不忍池のこの例のように極めて強い「隔離性」を 持つと考えられる空間を「独立島型」と呼ぶことに する。

b ) 弁天島型

「陸橋及び橋によって陸地と繁げられた人工島及 び自然の島」をいう。

不忍池の独立島には寛文 10 年(1670)頃に橋力架 
けられた。更に、茶屋が作られ遊興空間化すること で名所となった。（図－6）「弁天島型」は、この ように陸域と島か離れている（「隔離性」を持つ） ことによって逆に、人を誘う性格か強い(「誘引性」 を持つ）と考えられる空間をいう。

c) 突出型

「平面形状に於て水面貸に突出する形態」をいう。 金沢州崎明神の前面には、水面に凸状の水際線を 人工的に作った遊興空間が見られた。(図ー7)こ のように、水面に凸状の水際線を持った空間には遊 興空間や宗教空間を作ることが多く見られた。また、 神社の前面の突出形状の地先の水面中に鳥居か㯰か れていた例もあった。日本庭園の池でも啉状の地形 の先端水面中に「岩鼻」と呼ばれる石を置くことが あるが、これなどは、水面へ流出する意識を象徽化 したものといえる。

このように「誘引性」を利用した空間を「突出型」 と呼ぶことにする。

\section{d) 天保山型}

「山や運河、入り江等が造られ多機能化している 人工島」をいう。(図-8)

天保2、3年頃(1831、2)、大坂の淀川河口部に川 浚いの土砂によって天保山という人工島が作られた。 この人工島はそれ自体、航海の目標という役目を持 っていたが、大坂市民の一大レクリエーションの場 としても栄えた。陸地とは橋で結ばれ、丘が作られ、 島の回りには樹木が植えられ、陸域に近い方には入 り江が、先端部は臀筫茶屋が並んでいた ${ }^{11} 1,121,13$ $\therefore$

このように人々を楽しませ、居心地をよくする様 々な機能を取入れた「担点性」に富む人工島を特に
「天保山型」と呼ふことにする。

e）分水型

「水面を主水面と副水面に分割する空間」をいう。 不忍の池には、池と排水用の調整池 (悪水溜り) を分割する新土手と呼ばれる土地が延亭から宝暦(1 747-1752)及び文政年間(1819-1829)に作られていた 14)、15)。この土地には茶屋が並び、レクリエーショ ンの場として著名であった。また、新田の用水、悪 水抜きとして開削された大坂の十三間堀川は、沿海 運河 ${ }^{16)}$ の役割も果たし、堤には松並木が植えられ、

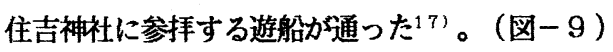

また、このような二つの異なった顔の水面に囲ま れた土地は遊興空間化、プロムナード化しやすいと 考えられる。「誘引性」のように端点に水面や神社 等の目標を持たずに、人がぶらぶら歩いたり、遊ん だりするこの空間の持つ特性を「誘歩性」と呼び、 このような空間を「分水型」と呼ぶ。

6 水辺のアース・デザインのデザイン原則

(1) 原地形と水辺のアース・デザインの型における 空間特性

原地形、アース・デザインの諸型から抽出された 水辺の空間特性をまとめると表一4のようになる。 空間特性は「隔離性」以下、5つの特性が抽出でき た。

(2) アース・デザインにおける原地形の空間特性の 洗練及び強化

諸型の分析から、アース・デザインの型は原地形 の持つ空間特性を洗練、強化していることが分かっ た。例えば、アース・デザインの「突出型」は「崎」 型の持つ「誘引性」を、「隅入り型」は「浦型」の

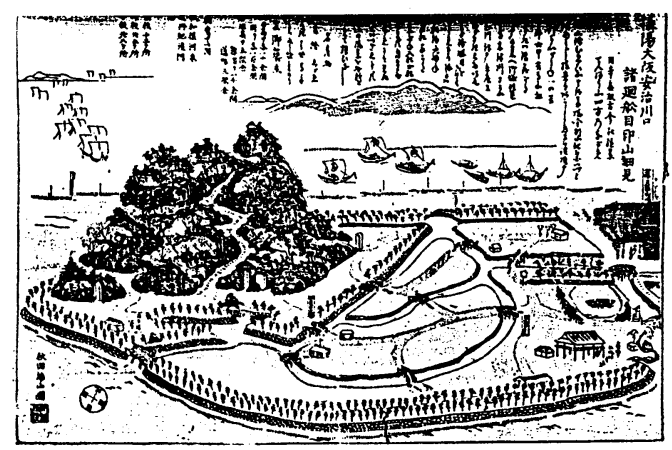

図-8 天保山（天保山型）
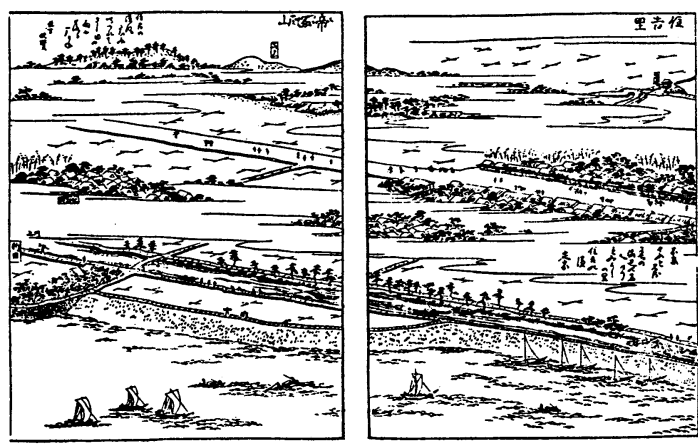

図-9 大坂十三間堀川 (分水型) 
表 -4 空間特性の一覧

\begin{tabular}{|c|c|c|c|c|}
\hline \multirow{2}{*}{\multicolumn{2}{|c|}{ 空間特性 }} & \multirow{2}{*}{ 内 容 } & \multicolumn{2}{|r|}{ 晆 } \\
\hline & & & 原地形 & アース・デザイン \\
\hline \multirow[b]{2}{*}{ 人の行動に関する } & 的離性 & 水面によって陸域か亚離され行けないこと & 「中州了島」 & 「独立禺 $\delta$ 弁天毒 $反$ 天保山」分水」 \\
\hline & 拠点性 & 居心地のよい空間であること。 & 「浦」 & 「蝈入与内水面」 \\
\hline \multirow[t]{2}{*}{ 空間特性 } & 誘引性 & $\begin{array}{l}\text { 人を誘う性格を持つこと. 端点に目標を持 } \\
\text { つ. }\end{array}$ & $\begin{array}{l}\text { 「崎」「砂州了 } \\
\text { 「中州「岛」 }\end{array}$ & 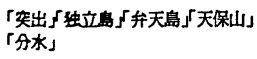 \\
\hline & 誘歩性 & $\begin{array}{l}\text { 人を歭かせる性格を持つこと. 端点に目標 } \\
\text { を持たない. 纾引性の一形態. }\end{array}$ & 「础州」 & 「分水与地堤了 \\
\hline $\begin{array}{c}\text { 土地利用に関する } \\
\text { 空間特性 }\end{array}$ & 利用差別性 & 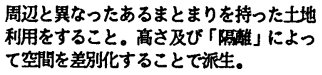 & 「岳」 & 「独立島 $\sqrt{ }$ 弁天島」天保山」「分水」 \\
\hline
\end{tabular}

アース・デザインの諸型は、 「誘引性」「批点性」「隔離性」 という空間特性に対応する「突 出」「隅入り」「島」という 3 つの原初的な型を極として、そ れらの3つの空間特性を以下に 述べる「純化」「複合化」「強 化」の組合せでデザイン的に関 連づけることができることが分 かった。(図ー10)

1)純化 (いくつかの空間特 性を一つの空間特性だけ にすること）

例 : 分水型 $\rightarrow$ 堰堤型（誘歩性の純化） 2)複合化（いくつかの空間特性を組み合わせる こと)

例 : 弁天島 =誘引性+隔離性 出島型 =誘引性+隔離性 天保山型二誘引性十隔離性+扰点性 3)強化 (一つの空間特性の機能を十分に発揮で きるようにすること）

例 : 突出型 $\rightarrow$ 出島型（誘引性の強化）、 隅入型 $\rightarrow$ 内水面型（抏点性の強化） 弁天島型 $\rightarrow$ 天保山型（扰点性の強化） 例えば、誘引性を持つ「突出型」のデザインに「 島型」を特徵づける空間特性である「隔離性」を付 加したものが「弁天島型」「出島型」のデザインと

(3) アース・デザインの型の相互間連
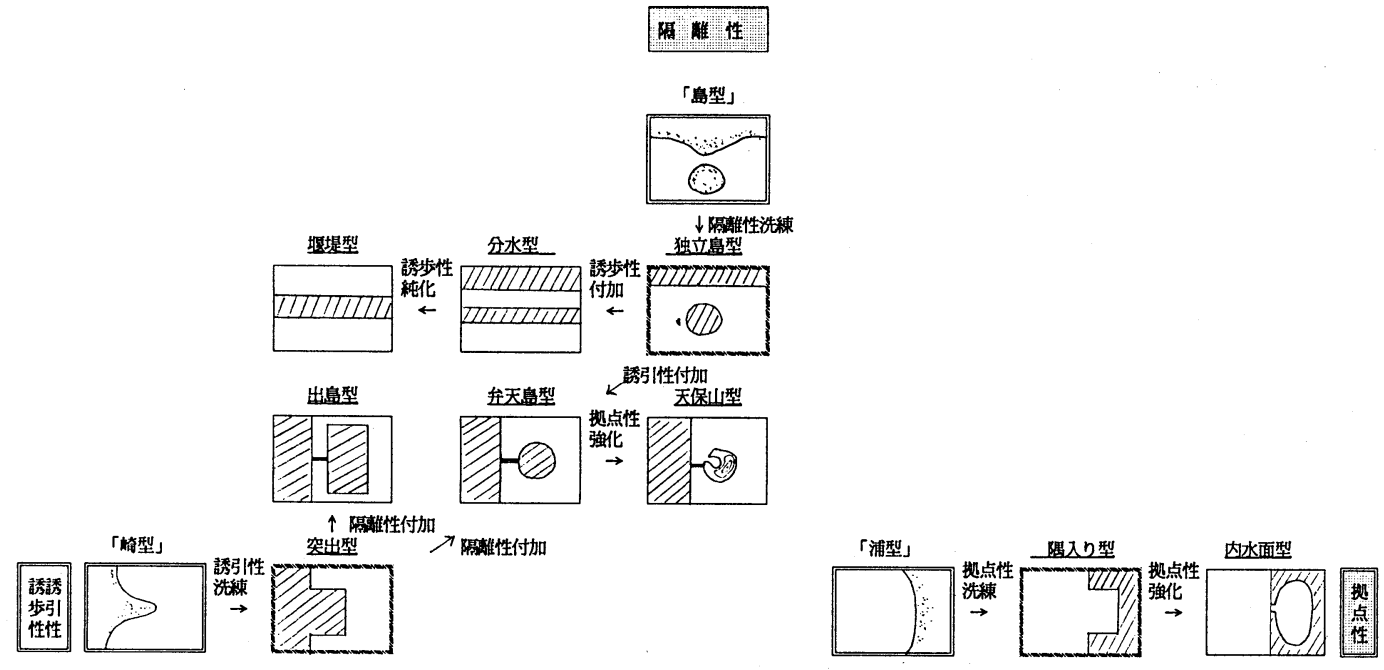

図-10 水辺のアースデザインの相互関連図 
なる。「隔離性」が加わることによって、逆に人を 誘う性格である「誘引性」か蟲化されると考えられ る。

この「弁天島型」のデザインに「隅入り型」を特 徵づける「起点性」を付加したものが、「天保山型」 のデザインであると言える。「天保山型」は島部の 空間が内水面、運河、丘等をもって多機能化したも のであり、島部の㧋点性が増すと共に、誘引性も增 していると考えられる。

\section{7 結論}

以上の研究により、

(1) 現在の水辺整備において等閑視されていた地形 の扱いを伝統的な水辺の原地形及びアース・デザ インの型として発掘し、その空間特性を抽出、整 理した。

(2) 伝梳的な水辺のアース・デザインは、水辺の本 来持つている空間特性を洗練、強化する行為であ ること及び、その洗練、強化の手法を明らかにし た。

(3) 原地形及びアース・デザインの型がばらばらに 存在するのでなく空間特性の

1) 純化

2）複合化

3）強化

の組合せにより体系的に把握することができるこ とを明らかにした。
参考文献

1)篠原 修、武田 裕、伊藤 登、岡田一天：「河 川微地形の形態的特徵とその河川景観設計計へ応 用」、土木計画学研究・論文集 $1986 \cdot 10$

2)横内憲久十横内研究室『ウオータフロント開発の 手法』鹿島出版会 1988

3)土木学会『水辺の景観設計』技報堂出版 1988

4)中村良夫、岡田一天、吉村美媇「河川空間におけ る人の動きのパターンの分析とその河川景篗虏計 への応用」土木計画学研究・論文集 $1987 \cdot 11$

5)伊藤 登、長谷川智也、瀬尾潔、武田 裕：「河 川風景主義からみた河川活動空間と景観設計手法」 土信画学研究・論文集 $1987 \cdot 11$

6)篠原 修、伊藤 登「水辺空間の設計と演出」 『自治体と土地・資源』学陽書房 1989

7) 『東京市史稿・港湾編』

8)深川区史編䈢会『江戸深川情緒の研究』有邦書店 9)小林安茂『上野公園』公園文庫 1980

10)豊島寛彰『上野公園とその付近』芳洲書院 1962

11）『明治以前日本土木史』土木学会 S S 11

12)暁鐘成『天保山名所図会』天保6(1835)

13)暁鐘成『浪華の賑ひ』嘉永 4(1851)

14）『東京市史稿・遊園篇』

15）『台東区史』

16)鈴木理生『江戸の都市計画』三省堂 1988

17）『日本歴史地名体系28 - 大阪府の地名』平凡社 1986 